\title{
Effect of Service Quality and Location to Tourist Loyalty Towards a New Normal
}

\author{
Erni Ummi Hasanah \\ Faculty of economics and business \\ Janabadra University \\ Yogyakarta, Indonesia \\ erni_uh@janabadra.ac.id
}

\author{
Danang Wahyudi \\ Faculty of economics and business \\ Janabadra University \\ Yogyakarta, Indonesia \\ danangwahyudi10mei@gmail.com
}

\begin{abstract}
We examined the effect of service quality and location on tourist loyalty with tourist satisfaction as a moderating variable. This study's primary data used in this study aims to examine the perceptions of tourists who have visited several tourist objects in Srimulyo Village, including Bukit Tompak Hill, Gerbang Banyu Langit, and Pasar KebonPring. This study uses path analysis to identify the effect of service quality and location on tourist loyalty with the intervening variable tourist satisfaction. Our conclusion shows that service quality and location's exogenous variables significantly positively affect tourist satisfaction and loyalty. We recommend that you clean up and prepare to welcome touriststowards a new normal in the tourist village.

Keywords: ServiceQuality, Location, Satisfaction, Loyalty, New Normal
\end{abstract}

\section{INTRODUCTION}

Srimulyo Village is one part of The Bantul district currently being aggressively developing the village's tourist potential. From the 22 hamlets in Srimulyo village, 17 tourist destinations are grow categorized. The growth categories of each tourist village vary. Several tourist village destinations developed and well developed. But on the other hand, some tourist destinations are still categorized as for- beginners (embryos), for the category of embryonic tourist destinations in the tourist village of Srimulyo, including GunungBangkel, Bukit Tompak, Puncak Bucu, WatuAmben Tourism. Meanwhile, tourist destinations categorized as advanced include Bukit Bintang, Pasar KebonPring, Gerbang Banyu Langit, Taman Nggirli.

The concept developed by the tourist village of Srimulyo is community-based tourism. One of the factors in the tourism village of Srimulyo is the intense promotion on various social media platforms and the support of each good tourist service to tourists /visitors. Besides, tourist location factors that are easily accessible and accessible to tourists who support the tourist village of Srimulyo.

Service is an essential factor in a business in the service sector, including tourism services, where customers will feel satisfied if the service provided is exemplary. But customers will leave if the service provided is not satisfactory. Also, supported by complete and eligible facilities and affordable prices, it will make customers feel satisfied. Of course, it will be the key to the service company'ssuccess to improve informationand build customer satisfaction through service quality.

[1]Service quality must start with customer needs and end with customer perceptions. Customer perception about service quality is one of the determinants of marketing success. The concept of good service will provide opportunities for companies to compete in seizing consumers. Meanwhile, the service concept's Performance creates a competitive situation to convince customers, strengthen brand image and sales.

[2]State that the determinants of consumer loyalty include service quality. Service quality is an effort to fulfill consumer's needs and desires and the accuracy of delivery in balancing consumer expectations[3]. [4]Statesthat location, product quality, significant effect on purchasing decisions.

Companies need a product that has a price by following the appropriatecustomer location. The company faces challenges in dealing with its customers because, at this time, customers can more freely choose products and services that suit their needs and desires. It shows that location also affects the purchase of a product or service. The result of a customer evaluation of a product or service that can meet expectations or satisfy it, then in the future, there may be repeated purchases.

Tourism is an intangible product, so tourist attraction, or what is also called a tourist attraction, is very important. A Tourist attraction is a potential that encourages tourists to visit a tourist destination. It must pay attention to $3 \mathrm{~A}$ aspects, namely Attraction, Accessibility (easilyaccessible), and Amenities (facilities). Besides, products or services that can satisfy our products or services can provide something that the customer is looking for to the customer's level. High satisfaction causes customers to behave positively towards a particular product or service, which causes emotional attachment to location, resulting in increased customer loyalty or loyalty. So in this study, an investigation will be carried out how the effect of service and site on loyalty

Formulation of the problem

1. How does service quality affect tourist satisfaction?

2. How does location affect tourist satisfaction?

3. How does service quality affect tourist loyalty?

4. How does location affect tourist loyalty?

5. How does customer satisfaction affect tourist loyalty? 


\section{LITERATURE REVIEW}

A. Service Quality

Service quality is an effort to fulfill consumer's needs and the accuracy of its delivery in balancing consumer expectations [3].

Service Quality Indicators

a. Physical evidence (tangible).

b. Reliability

c. Responsiveness

d. Assurance

e. Empathy

\section{B. Location}

[5]Location is the physical structure of a business that is the main component that sees -company undertaking its business and providing consumer's service channels. Indicators measure location according to[6].Location Indicators:

a. Access

b. Visibility

c. Parking lot

\section{Customer Satisfaction}

Customer satisfaction is a feeling of pleasure or disappointment for someone who arises after comparing the perception of a product's Performance and its expectations [7].Customer Satisfaction Indicators:

a. hope.

b. performance

c. assessment.

\section{Customer Loyalty}

Customer Loyalty is a deep commitment from consumers to make repeated purchases of specific products or services consistently in the future $[8,9]$. Customer Loyalty Indicators:

a. Repeat purchase

b. Telling positive things to friends/ family

c. The attitude of choosing a product even though the transaction costs are rising.

E. Theoretical Framework

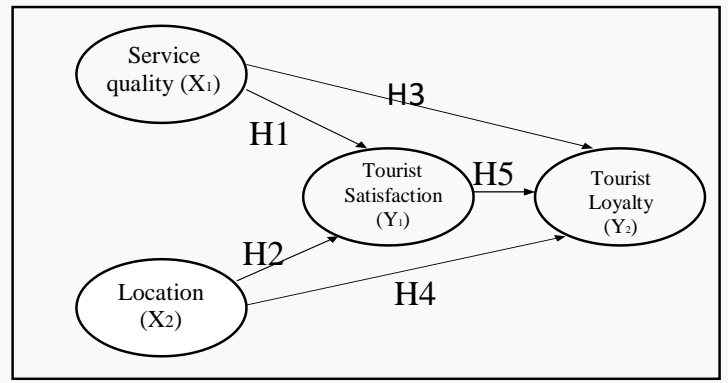

F. Hypothesis

$\mathrm{H} 1$ : Service quality has a positive effect on tourist satisfaction
$\mathrm{H} 2$ : Location has a positive effect on tourist satisfaction.

H3: Service quality has a positive effect on tourist loyalty.

H4: Location has a positive effect on tourist loyalty.

H5: Customer satisfaction affects tourist loyalty

\section{RESEARCH METHODS}

A. The research variables used in this study are:

1. Exogenous Variables

Exogenous variables influence the emergence of dependent either positively or negatively, i.e., if there are exogenous variables, endogenous variables are also present with each unit of increase in the exogenous variable.There is also an increase or decrease. in endogenous variables[10]. In this study, there are two exogenous variables, namely:

a. Quality of Service (X1)

b. Location (X2)

\section{Endogenous Variables}

Endogenous variables are variables that are of significant concern to researchers. This endogenous variable is the result of exogenous variables. An endogenous variable in this research is Customer Loyalty (Y2).

3. Intervening variable (intervening variable)

Intervening variables affect the relationship between the independent and the dependent variable, but this variable cannot be observed and measured.Comparison between the impression of the Performance (result) of a product or service with Kotler and Keller [11].

\section{Population}

The population in this study were tourist who made tourist visits in the tourist village of Srimulyo, especially at Bukit Tompak, Banyu Langit and,KebonEmpringin the last six months, July 2019 - December 2019.

\section{Sampling Techniques}

The sampling technique used is non-probability sampling, namely purposive sampling. This study's purposive sampling method is to take the sample based on the number of tourist visits to the Tourism Village of Srimulyo Bantul.The criteria for tourists as a sample are those who have visited at least two or more times.

\section{Type of Data}

This study uses primary data, namely, data obtained directly from the source (respondents).

\section{Data collection technique}

The data collection technique used in this research uses a closed questionnaire by providing a set of questions or statements that already have alternative answers, distributed directly to respondents.

7. Data Analysis Method

Instrument Test

1. Validity Test 
The validity test is used to determine whether or not the questionnaire is distributed. The research resultis valid if there is an equation between the data collected and the data that occurs on the object under study. In this study, the validity analysis of the research instrument used the Product Moment Correlation Coefficient formula.

2. Reliability Test

To find out that the questionnaire's questions in the questionnaire are consistent, it is detected by a reliability test. A variable is said to be reliable if the Cronbach Alpha value is $>0.60$.

This study used quantitative data analysis methods. The data will be analyzed for decision-making so that the data obtained can provide useful information for this study. This study uses a path analysis model because between the independent variables and the dependent variable.This study consisted of three variables. Exogenous (independent) variables are service quality and location, mediating (intervening) variables are tourist satisfaction, while endogenous (dependent) variables are tourist loyalty.

3. Normality Test

The normality test is a test that is performed as a prerequisite for conducting data analysis. The normality test is carried out before the data is processed based on the research models proposed. The data normality test aims to detect the distribution of data in one variable used in the study. Excellent and proper data to prove the research models are normal distribution data. The normality test used is the Kolmogorov-Smirnov test. Data is normal if the significant value is greater than $0.05(\mathrm{P}>$ 0.05). Conversely, if the significant value is less than 0.05 at $(\mathrm{P}<0.05)$, then the data is said to be abnormal.

4. Test the Effect of Mediation (Intervening)

[12] States that a variable is called an intervening variable if the variable affects the relationship between the predictor (independent) and the criteron variable (dependent). Mediation testing can be carried out by a procedure developed by [13]known as the Sobel Test.

\section{DATA ANALYSIS RESULTS}

A. Characteristics of Respondents

Respondents in this study were 100 people, all of whom were tourists in the tourist village of Srimulyo Bantul. In this study, the characteristics you want to know are age, frequency of visits, and respondent's occupation. Respondents characteristic data are presented in the following tables;

Table 1

Characteristics of Respondents by Age, Frequency of Visit andProfession

\begin{tabular}{|c|l|c|c|}
\hline NO & CATEGORY & FREQUENCY & PROSENTAGE \\
\hline \multicolumn{4}{|c|}{ Characteristics of Respondents - Age } \\
\hline 1 & $21-25$ & 14 & $14 \%$ \\
\hline 2 & $26-30$ & 22 & $22 \%$ \\
\hline 3 & $31-35$ & 26 & $26 \%$ \\
\hline 4 & $36-40$ & 13 & $13 \%$ \\
\hline
\end{tabular}

\begin{tabular}{|c|c|c|c|}
\hline $\mathrm{NO}$ & CATEGORY & FREQUENCY & PROSENTAGE \\
\hline 5 & $41-45$ & 13 & $13 \%$ \\
\hline 6 & $45-50$ & 9 & $9 \%$ \\
\hline 7 & $51-55$ & 3 & $3 \%$ \\
\hline & TOTAL & 100 & $100 \%$ \\
\hline \multicolumn{4}{|c|}{$\begin{array}{c}\text { Characteristics of Respondents - Frequency of } \\
\text { Visits }\end{array}$} \\
\hline 1 & $1 \mathrm{X}$ & 0 & $0 \%$ \\
\hline 2 & $2 X$ & 0 & $0 \%$ \\
\hline 3 & $3 \mathrm{X}$ or more & 100 & $100 \%$ \\
\hline & TOTAL & 100 & $100,0 \%$ \\
\hline \multicolumn{4}{|c|}{ Respondent Characteristics - Occupation } \\
\hline 1 & $\begin{array}{l}\text { government } \\
\text { employees }\end{array}$ & 10 & $10 \%$ \\
\hline 2 & $\begin{array}{l}\text { Private } \\
\text { employees }\end{array}$ & 20 & $20 \%$ \\
\hline 3 & entrepreneur & 15 & $15 \%$ \\
\hline 4 & Student & 20 & $20 \%$ \\
\hline 5 & $\begin{array}{l}\text { College } \\
\text { student }\end{array}$ & 35 & $35 \%$ \\
\hline & TOTAL & 100 & $100,0 \%$ \\
\hline
\end{tabular}

Based on the characteristics of the age of the respondents in table 1, most of them are 31-35 years old, and there are 26 tourists $(26 \%)$ followed by the 26-30 years old with 22 tourists $(22 \%)$ and $21-25$ years old 14 tourists (14\%). All respondents have made more than $2 \mathrm{x}$ visits to tourism objects in Srimulyo Village (100\%). Respondents with student jobs were 35 tourists $(35 \%)$, followed by private employees and students as many as 20 employees (20\%).

\section{B. Test Instruments}

1. Validity Test

The validity test result that the statement items on the variables of service quality, location, customer satisfaction, and customer loyalty result in the value of $r$ count is more significant than $r$ table. The conclusion is that the validity test result for for the four variables are valid, so they are suitable for use as a research instrument.

C.Reliability Test

Table 2

Reliability Test

\begin{tabular}{|c|c|c|c|}
\hline Variables & $\begin{array}{c}\text { Cronbach's } \\
\text { Alpha }\end{array}$ & Criteria & explanation \\
\hline $\begin{array}{l}\text { Service } \\
\text { quality }\end{array}$ & 0,833 & \multirow{4}{*}{$\begin{array}{c}\text { Cronbach } \\
\text { Alpha > } \\
0,6\end{array}$} & Reliable \\
\hline Location & 0,727 & & Reliable \\
\hline $\begin{array}{l}\text { Tourist } \\
\text { Satisfaction }\end{array}$ & 0,843 & & Reliable \\
\hline $\begin{array}{l}\text { Tourist } \\
\text { Loyalty }\end{array}$ & 0,834 & & Reliable \\
\hline
\end{tabular}

Referring to table 3 , the reliability test produces a value 
greater than the required alpha value of 0.60.This means that each variable is reliable.

Table 3

Normality Test Results

\begin{tabular}{|c|c|c|c|c|c|}
\hline \multicolumn{6}{|c|}{ Ore-Sample Kolmogorov-Smirrov Ted } \\
\hline & & $\begin{array}{c}\text { Kualita } \\
\text { Pelayanan }\end{array}$ & Lokøi & $\begin{array}{l}\text { Kepuasaan } \\
\text { Wis atawan }\end{array}$ & \begin{tabular}{|c} 
Loyalita \\
Wis atawan
\end{tabular} \\
\hline \multicolumn{2}{|l|}{ N } & 100 & 100 & 100 & 100 \\
\hline \multirow{2}{*}{$\begin{array}{l}\text { Normal } \\
\text { Parameters }\end{array}$} & Mean & 34,3 & 21,45 & 19,5 & 22,55 \\
\hline & Std. Deviation & 4,79 & 2,735 & 3,474 & 2,634 \\
\hline \multirow{3}{*}{$\begin{array}{l}\text { Most Extreme } \\
\text { Differenoses }\end{array}$} & Abs alute & 0,076 & 0,125 & 0,083 & 0,102 \\
\hline & Positive & 0,075 & 0,09 & 0,073 & 0,102 \\
\hline & Negatike & $-0,066$ & $-0,125$ & $-0,08:$ & $-0,0 \%$ \\
\hline \multicolumn{2}{|c|}{ KolmogoravSmimov2 } & $0, \pi 9$ & 1,247 & 0,888 & 1,022 \\
\hline \multicolumn{2}{|c|}{ Asymp. Sig. (2-tailed } & 0,612 & 0,089 & 0,5 & 0,247 \\
\hline
\end{tabular}

The normality test in this study is shown in Table 4 using the Kolmogorov-Smirnov. The SPSS test results show sig $>\alpha(0.05)$ seen from the Asymp column. Sig (2-tailed) with a value of service quality (0.612), location (0.089), tourist satisfaction (0.500), and tourist loyalty (0.247) indicates that the sample data is normally distributed. Mediation Test.

Table 4

\section{Correlation between variables}

\begin{tabular}{|l|l|l|l|l|l|l|l|}
\hline Variable & & Variable & Estimate & S.E & C.R & P & Label \\
\hline satisfaction & $<\ldots$ & Quality &, 217 &, 065 & 3,331 & $* *$ & par 1 \\
\hline satisfaction & $<\ldots$ & Location &, 438 &, 114 & 3,849 & $* *$ & par 2 \\
\hline loyalty & $<\ldots$ & Quality &, 027 &, 045 &, 608 &, 543 & $\operatorname{par} 3$ \\
\hline loyalty & $<\ldots$ & Location &, 264 &, 080 & 3,311 & $* *$ & par 4 \\
\hline loyalty & $<\ldots$ & Satisfaction &, 367 &, 060 & 5,570 & $* *$ & par 5 \\
\hline
\end{tabular}

By using the Amos software version 20.0, it can be seen in Table 5 that there is a positive and significant influence between the 3 variables except for the variable service quality on tourist loyalty, which has not shown significant results.

Table 5

RMR, GA, AGA, PGFI

\begin{tabular}{|l|c|c|c|c|}
\hline Model & RMR & GFI & AGFI & PGFI \\
\hline Default model & 1,355 & 0,965 & 0,646 & 0,096 \\
\hline Saturated model & 0 & 1 & & \\
\hline $\begin{array}{l}\text { Independenoe } \\
\text { model }\end{array}$ & 3,591 & 0,638 & 0,397 & 0,383 \\
\hline \multicolumn{5}{|c|}{ Sumber: Data Primer di olah,2020 } \\
\hline
\end{tabular}

The GFI (goodness of fit index) test results show 0.965 , which means that the value is close to 1.0 (perfect fit), so it is a good fit.

The conclusion is that the GFI value of 0.965 is in the good fit category.
Table 6 CFI

\begin{tabular}{|c|c|c|c|c|c|}
\hline \multirow{2}{*}{ Model } & NFI & RFI & $\mathrm{IFI}$ & TLI & \multirow{2}{*}{ CFI } \\
\hline & Delta1 & rhol & Delta2 & rho2 & \\
\hline Default model & 0,922 & 0,534 & 0,932 & 0,57 & 0,928 \\
\hline Saturated model & 1 & & 1 & & 1 \\
\hline $\begin{array}{l}\text { Independence } \\
\text { model }\end{array}$ & 0 & 0 & 0 & 0 & 0 \\
\hline
\end{tabular}

The result of this study shows in table 7 that the CFI column gets a value of 0.928 . Comparative Fit Index (CFI) is a cumulative suitability index.

The results of the CFI index value show that the model has a good level of suitability. The recommended acceptance value is CFI $>0.90$. So it can be concluded that a value of 0.928 is a good fit.

\section{DISCUSSION}

Based on the path analysis value using Amos software version 20.0 above, the test results for each hypothesis are as follows:

1. Effect of Service Quality on Tourist Satisfaction in Srimulyo Tourism Village, Piyungan, Bantul.

This study proves the first hypothesis, which states thatservice quality positively affects tourist satisfaction. The first factor affecting tourist satisfaction is service quality. The conclusion from Table 5 is that service quality has a positive and significant effect on tourist satisfaction. This study supports previous research conducted by [14] on the impact of service quality on consumer loyalty with satisfaction as a mediating variable (study at Toko Basuki Jaya Yogyakarta).

2. The Effect of Price Perspection on Tourist Satisfaction in Srimulyo Tourism Village, Piyungan, Bantul.

This study proves the second hypothesis, which states that location has a positive effect on customer satisfaction. One of the factors that influence tourist satisfaction is the location of the tourist attraction. From the results that can be seen in Table 5 , it can be concluded that the location of tourism objects has a positive and significant effect on customer satisfaction. This research supports [15] previous study that service and location affect motorcycle customer satisfaction and loyalty in Denpasar.

3. Effect of Service Quality on Tourist Loyalty in Srimulyo Tourism Village, Piyungan, Bantul.

This study has not proven the third hypothesis, which states that service quality positivelyaffects customer loyalty. One of the factors that affect customer loyalty is service quality. Based on table 5, we conclude that service quality has no effect on tourist loyalty.

4. The Influence of Location on Tourist Loyalty in Srimulyo Tourism Village, Piyungan, Bantul.

This study proved the fourth hypothesis, which states that location has a positive effect on customer loyalty. One of 
the factors that affect customer loyalty islocation. Table 5 illustrates that location has a significant positive effect on tourist loyalty. The results of this study support previous research conducted [16]regarding the influence of service quality, location, and customer value on customer loyalty through customer satisfaction as an intervening variable towards consumers of the IM3-Indosat cellular card.

5. The Influence of Customer Satisfaction on Tourist Loyalty in SrimulyoTourist Village, Piyungan, Bantul.

This study proves the fifth hypothesis, which states that satisfaction has a positive effect on tourist loyalty. From the results that can be seen in Table 5 , it can be concluded that tourist satisfaction has a positive and significant impact on customer loyalty. The results of this study support the research conducted [17] on the effect of advertising, location, service quality on customer loyalty mediated by customer satisfaction (a study on consumers of the PlayStation rental business).

\section{CONCLUSION AND SUGGESTIONS}

\section{A. Conclusions}

a. Service Quality has a positive and significant effect on tourist satisfaction,

b. The location has a positive and significant impact on tourist satisfaction,

c. Service quality does not affect on tourist loyalty,

d. The location has a positive and significant effect on tourist loyalty,

e. Customer satisfaction has a positive and significant impact on customer loyalty.

\section{B. Suggestions}

a. The results of this study indicate that service quality positively affects tourist satisfaction and loyalty.Therefore, the tourism village in providing quality services must increase.

b. The results of this study indicate that the location positively influences tourist's satisfaction and tourist's loyalty where the parking lot indicator gets the lowest score (3.45). Therefore, the tourist attraction of Srimulyo Village must pay attention to parking lots to provide comfort for tourists.

c. As the results of this study indicate that tourist satisfaction positively influences tourist loyalty, according to the respondent's satisfaction indicators, services get the lowest score (3.17). Therefore, tourism objects must pay more attention to tourist's input or suggestions from tourists about deficiencies that cause tourists to feel less satisfied with the tourism object manager's services.

d. Recommendationtowards a new normal, tourist village must clean up and be prepared to welcome tourists.

\section{REFERENCES}

1. Adi, Rifqi P.2013. Pengaruh Kualitas Produk Dan Kewajaran Harga Terhadap Loyalitas Dengan Kepuasan Konsumen Sebagai
Variabel Intervening.http://journal.unnes.ac.id/sju/index.php/maj ( diakses 19 Maret 2020 ).

2. Cahyadi, Imam F. 2014. Pengaruh Lokasi, Atribut Produk Dan Persepsi Risiko Terhadap Keputusan Pembelian Susu Formula. Skripsi. UNY.

3. Masruchin, Charis dan Marlien. 2017. Analisis Kualitas Produk, Citra Merek Dan Lokasi Terhadap Loyalitas Pelanggan Dimediasi Kepuasan Pelanggan (Studi Pada Pelanggan Nissan Di Kota Semarang Tahun 2017). Prosiding SENDI_U 2018. ISBN: 978-979-3649-99-3.

4. Nugroho, Wisnu Adhi Dan Rahmat Hidayat. 2017. Pengaruh Kenyamanan Dan Kepercayaan Produk Terhadap Loyalitas Pelanggan (Studi Pada Konsumen Go-Jek Di Bandung Tahun 2017). E-Proceeding Of Applied Science : Vol.3, No.3 Desember 2017.

5. Nurullaili Dan Andi W. 2013. Analisis Faktor-Faktor Yang Memengaruhi Loyalitas Konsumen Tupperware (Studi Pada Konsumen Tupperware Di Universitas Diponegoro). Jurnal Administrasi Bisnis, Volume 2, Nomor 1, Maret 2013.

6. Oktavia,Dian C. 2013. Analisis PengaruhKualitas Layanan Dan Persepsi Nilai Terhadap Loyalitas Pelanggan Dengan Kepuasan Pelanggan Sebagai Mediasi.Skrpsi.Undip,

7. Permatasari, Cicilia Desy W. 2015 Pengaruh Kepercayaan, Keamanan, Persepsi Resiko Dan Kualitas Pelayanan Terhadap Keputusan Pembelian Secara Online (Studi Pada Pengguna Situs Olx.Co.Id D/H Berniaga.Com). Skripsi. Semarang: Universitas Dian Pradipta, Dwitya.2018. Pengaruh Periklanan, Lokasi, Kualitas Pelayanan Terhadap Loyalitas Pelanggan Yang Dimediasi Olehkepuasanpelanggan (Studi Pada Konsumen Usaha Rental Playstation) Twins Rajabasa.Skripsi.Universitas Lampung.Nuswantoro.

8. Pradipta, Dwitya.2018. Pengaruh Periklanan, Lokasi, Kualitas Pelayanan Terhadap Loyalitas Pelanggan Yang Dimediasi Olehkepuasanpelanggan (Studi Pada Konsumen Usaha Rental Playstation) Twins Rajabasa.Skripsi.Universitas Lampung.

9. Putri, Yulia L Dan Hardi Utomo. 2017. Pengaruh Kualitas Pelayanan Terhadap Loyalitas Pelanggan Dengan Kepuasan Sebagai Variabel Intervening. Among Makarti Vol.10 No.19, Juli 2017.

10. Riduan dan Akdon, 2007, Rumus dan Data dalam Analisis Statistik, Bandung: ALPHABETA.

11. Simanullang, Sudarman S.2018. Analisis Pengaruh Kualitas Pelayanan Terhadap Loyalitas Konsumen Jasa Transportasi Online Dengan Kepuasan Konsumen Sebagai Variabel Moderating (Studi Kasus Mahasiswa Fakultas Ekonomi dan Bisnis Islam Jurusan Ekonomi Islam 2014-2016 UIN-SU) .Skripsi.UIN Sumatra Utara.

12. Sukandi, Pipin Dan Dody Kurnia. 2017 Pengaruh Kualitas Pelayanan Customer Service Terhadap Loyalitas Konsumen Jurnal Sustainable Competitive Advantage-7 (Sca-7) Feb Unsoed Vol 7 No 1 (2017).

13. Tahuman, Zainuddin. 2016. Analisis Faktor-Faktor Yang Mempengaruhi Loyalitas Pelanggan Serta Dampaknya Terhadap Keunggulan Bersaing. Jurnal Riset Bisnis Dan Manajemen Vol 4 ,No.3, Edisi Khusus Pemasaran \& Keuangan 2016: 445-460.

14. Umar, Husein. 2014. Faktor-Faktor Yang Memengaruhi Loyalitas Pelanggan Pada Penerbangan Low Cost Carrier. Jurnal Manajemen Transportasi \& Logistik (Jmtranslog) - Vol. 01 No. 02, Juli 2014

15. Utami,Arum P.2016. Pengaruh Bauran Pemasaran Terhadap Keputusan Pembelian Konsumen Di Minimarket Kopma Universitas Negeri Yogyakarta.Skripsi.Uny.

16. Usvita, Mega Dan Pipi Yestika S. 2013 Pengaruh Kualitas Pelayanan Customer Service Terhadap Loyalitas Nasabah Tabungan Sikoci (Studi Kasus Pada Nasabah Bank Nagari Cabang Ujung Gading). E-Jurnal Apresiasi Ekonomi.

17. Wicaksono, Zulfiqar A dan Wisnu Untoro.2015. Pengaruh Kualitas Layanan dan Kewajaran Harga Yang Dirasakan Terhadap Loyalitas Pelanggan Dimediasi oleh Kepuasan Pelanggan Fokus Manajerial 2015 - Vol. 13 No. 2 Hal. 121-132. (diakses 19 Maret 2020). 